\title{
India on stand-by for a plague of locusts
}

INDIA is standing by for a locust invasion on its borders with Pakistan. Five wireless-linked locust control centres have been established in the border states, and chemicals, men and machines rushed in as locust activity increases. An agreement has been signed between the two countries for a joint strategy to combat the menace. Field officers on either side of the border are meeting regularly to exchange information on locust swarms, egg-laying and emergence of hoppers.

If the locust threat materialises, it will be the second invasion this year. It was in mid-June that the first swarmlets of locusts invaded India. A rare change in wind pattern over the Arabian Sea brought them to Banaskantha and adjoining districts of Gujrat from their original breeding grounds in Africa. The Plant Protection Organisation of the Agriculture
Ministry swung into action and neighbouring states alerted. Benzene hexachloride dust, dusting machines and handpump sprayers were rushed in.

Swarmlets swept in across the IndiaPakistan border, and spread to Rajasthan, Haryana and Punjab. They came in small and thin waves. A swarmlet was hardly larger than $3 \mathrm{sq} \mathrm{km}$ in area - though a swarm as large as $27 \mathrm{sq} \mathrm{km}$ was also spotted in Rajasthan.

India's last locust plague, 16 years ago, destroyed half a billion rupees of standing crop. Except for spoiling leaves and some standing cotton crop in Haryana, the recent invasion did almost no damage-thanks to timely action by the Agricultural Departments of Punjab and Haryana.

Control rooms were set up and antilocust squads formed. Villagers were trained to report any sign of locust activity. Areas where the locust swarms had laid eggs were ploughed or sprayed with chemicals. The conventional methods of flame-throwing and digging trenches were also used in some villages, and eventually, all the swarmlets were either killed or paralysed, except one which managed to fly back to Pakistan across the Sutlej river.

The current locust concentration is in the largely desert Saurashtra-Kutch region of Gujrat. At this time of the year, heavy rains turn it into a marshland and a breeding and egg-laying ground for the locusts. Locust swarms have also laid eggs in a large number of villages in Rajasthan.

A total of 100 vehicles, five planes, two helicopters, 100 power dusters and 5,000 hand dusters have already been rushed to these border areas. Border Security forces and the Air Force are also on hand if needed.

Dilip M. Salwi

\section{Vietnam still looking for foreign aid}

VietnaM's appeal for more development aid seems to be having a mixed reception. Many countries and international agencies have signed technical and scientific aid agreements with the Vietnamese, but some now have reservations about starting new programmes. The United States refuses to consider any commitment to Vietnam until diplomatic relations are restored.

International organisations provide a substantial proportion of Vietnam's current aid revenue, and a number have commitments within the country. The World Food Programme, for example, has provided US \$89 million since April 1975 for emergency assistance, irrigation work, resettlement programmes in the 'new economic zones' and afforestation programmes. The United Nations Children's Fund is giving \$73 million from 1976-1979 to provide basic health care and primary education and to improve drinking water supplies. In addition the U.N. Family Planning Association (UNFPA) is already operating family planning programmes and will manufacture contraceptives; and the World Health Organisation (WHO) is, to take one example of its activities, training health care personnel.

Financial institutions such as the World Bank and the Asian Development Bank are also to make funds available for projects to improve irrigation, rehabilitate light industry, explore oil resources, and develop telecommunications.

UNESCO and the International Atomic Energy Association (IAEA) are two of the more scientificallyorientated agencies with an interest in Vietnam. UNESCO is helping to equip the Nha Trang Centre of Oceanography and to set up the Scientific Information and Documentation Centre. (Because of its concern in the field of the restoration of historical monuments, it is also being asked for assistance in restoring the former imperial capital of Hue.) The IAEA feels it could help with the application of isotope and radiation techniques to agriculture and ground water surveysboth given top priority in the country's development programme.

Vietnam is no longer at the top of the UN list of those in need of development assistance-that position is now taken by Angola and Mozambique. But interest in Vietnam has not waned. The report back in March of the Special Commission on Assistance to Vietnam was very well attended. The Soviet Union, China, and the nations of Eastern Europe have long supplied aid to Vietnam and more recently Sweden, Norway and Holland have also established commitments in the country. They are maintaining a keen interest in the redevelopment of the country and are involved in several specific projects.

Vietnam has given science and technology high priority, but most aid agreements favour technology. Those concerned more with science, and involving Western nations, are limited to India, France, West Germany, Canada, Switzerland and the Philippines. These agreements are mainly to provide advanced training for Vietnamese students.

Lack of technical equipment presents great problems for scientists in Vietnam. This means that research targets are not always met and-for biologists in particular-research programmes are sometimes postponed. The United Nations mission to Vietnam highlighted the needs of Vietnam's scientists, and the UN officials involved with the mission do not hide their disappointment at the apparent disinterest shown by countries supplying scientific aid. They admit, however, that they are not privy to the terms of every bilateral aid agreement and that some countries may be assisting by supplying scientists with vital equipment.

Britain, however, has no immediate plans to supply scientific aid. It is concerned with human rights in Vietnam. The Ministry of Overseas Development (ODM) and the Foreign and Commonwealth Office say that aid already committed to Vietnam will not be affected, but that no new agreements will be made until the government is reassured that human rights are not being violated.

But Britain is not alone. Sweden and Holland have expressed similar concern. They are worried about press reports of refugees leaving Vietnam; of the measures taken to restrict private enterprise in the south of the country; and of the means used to persuade people to move into the new economic zones. The British Government has also shown its concern about human rights in other countries and has 